\title{
Research on Chewing Gum: Questions of Ethics
}

\author{
Sonia Vieira \\ São Camilo University, São Paulo, Brazil \\ Email: soniavieira@merconet.com.br
}

How to cite this paper: Vieira, S. (2017). Research on Chewing Gum: Questions of Ethics. Open Journal of Philosophy, 7, 260264.

https://doi.org/10.4236/ojpp.2017.73016

Received: April 30, 2017

Accepted: July 18, 2017

Published: July 21, 2017

Copyright $\odot 2017$ by author and Scientific Research Publishing Inc. This work is licensed under the Creative Commons Attribution International License (CC BY 4.0).

http://creativecommons.org/licenses/by/4.0/

\begin{abstract}
Guidelines for clinical research and ethics committees are significant contributions to decision made in science and law. But since research methods need to follow the changes and the development of science, guidelines for clinical research have to be continuously revised. Many innovations are perceived for their intended beneficiaries as benefits. Unfortunately, this is not always true. Therefore two issues should be mandatory in discussions of research ethics committees: 1) What constitutes a harmful intervention? 2) What procedures should be established for obtaining data and evaluating their relevance? These questions are too broad and there are no ethical solutions that can leap off a paper. But an example can be worked on. Dental caries is a public health challenge in any country and chewing gum may have an effect with respect to plaque reduction, at least in a short period of time. But sugar chewing gum cannot be used as a positive control in biomedical researches. However, trials referred herein allocated participants for a sugar chewing gum group. Therefore, the aim of this critical review is to emphasize that such a procedure is an example of a conscious disregard for the consideration which is due to trial participants. Were these desirable researches themselves or they had other purposes?
\end{abstract}

\section{Keywords}

Research Methods, Ethics in Research, Chewing Gum, Chlorhexidine

\section{Introduction}

It is already known that dental caries is a biofilm-dependent oral disease and fermentable carbohydrates are the key environmental factor for its initiation and development (Paes-Leme, Koo, Bellato, Bedi, \& Cury, 2006). It has been suggested that sugar-free chewing gum used immediately after meals reduces caries. In fact, chewing gum may serve as an oral hygiene device when brushing may not be possible (Kakodkar \& Mulay, 2010). The observed caries reduction may be ascribed to saliva stimulation throughout the chewing process, the lack of sucrose 
and the inability of bacteria to metabolize polyols into acids (Mickenautsch, Leal, Yengopal, Bezerra, \& Cruvinel, 2007). Besides the observed caries reduction, it was suggested that chewing gum may improve aspects of cognitive function and mood (Smith, 2010). As a result, chewing gum manufacturers have made health promotion claims, suggesting, e.g., reparative action or substitution for mechanical hygiene (Imfeld, 1999).

\section{Experimentation without Restriction}

Can chewing gum prevent dental caries? Studies were conducted in Brazil in the eighties with a sucrose gum containing chlorhexidine digluconate, which had the commercial name of Den-den. There is no data on preclinical research or even on clinical trials, only a previous note by the author (Neder, 1981).

After the chewing gum was already being marketed, some articles were published in Brazilian journals. One of these articles (Lacaz-Netto, Macedo, \& Rossetini, 1986) describes a clinical trial carried out to compare the benefits of Denden with a gum sweetened with sorbitol and manitol and a sugar-packed gum (a positive control) with a negative control group. Six dental female students, twenty years of age on average were recruited and the trial went on for twelve days. The ethical implication of using a sugar-packed gum as a positive control was not even mentioned. Besides that, the small sample size undermines the reached conclusion that "any type of chewing gum is capable of reducing a high plaque index".

A second study (Pinheiro, Vono, Pavarini, Bijella, Bastos, Moraes, \& Silva, 1985) conducted in Brazil recruited fifty students, males and females, in a Dentistry School for two trials. The first trial sought to compare the effects of conventional chewing gum and Den-den on inhibition of dental plaque formation and the second sought to compare the effects of the same chewing gums on dental plaque dissolution. No difference between groups was observed in both trials.

Only after experimenting with human beings was an experiment finally conducted with rats. Thirty rats 20 to 21 days old were divided into three groups: the first group received Den-den added to the standard rat food; the second received conventional gum added to the standard rat food and the third group was the control. Researchers concluded that Den-den had neither anticariogenic effect nor reduced biofilm formation.

Afterwards, a chemical analysis revealed more than $70 \%$ of sucrose and a minimum amount of digluconate of chlorhexidine (approximately $0.02 \mathrm{mg} / \mathrm{unit}$ ) in Den-den formulation. There is an intuitive explanation for this: Den-den chewing gum was produced in a candy factory and, in order to mask the unpleasant taste of digluconate of chlorhexidine, sugar was added.

The fact is that the Department of Health Surveillance (Jornal do Brasil, 1984), now the National Health Surveillance Agency, which is subordinated to the Brazilian Institute of Health, prohibited the manufacture of Den-den chewing gum because of the misleading propaganda: "Den-den chewing gum fights dental caries and protects your teeth". According to the manufacturer, around fifty mil- 
lion units of Den-den were sold per month in Brazil. Is it reasonable to consider that many children were harmed?

Researchers from Michigan University carried out a double-blind cohort study with 1277 fourth graders in Belize, Central America, from 1989 to 1993, in order to compare, side by side, various chewing gum formulations (Mäkinen, Bennett, Hujoel, Isokangas, Isotupa, Pape, \& Mäkinen, 1995).

Children were examined by four calibrated dentists at baseline and after 16, 28 and 40 months on the program. Findings showed that sorbitol gum reduces caries rates, but xylitol gums are more effective. According to the authors, the most effective for caries prevention was the gum sweetened with xylitol chewed five times daily. Researchers also observed that sucrose gum usage leads to an increase in the caries rate. Is it possible they did not know that they would inevitably come to this conclusion? Anyway, the study carried out in Belize by researchers from Michigan University is an example of a double standard in an investigation: a sucrose chewing gum probably would not be tested in Michigan, USA, due the ethical implications.

In 1994 the Brazilian Association of Dentistry magazine (Editorial, O sorriso do chiclete, 1994) reported the Belize study, adding extemporaneous comments about Den-den. It starts by saying that "sorbitol, xylitol or chlorhexidine...(are) ingredients which researchers test in order to measure the efficiency of chewing gum (with these ingredients) to reduce dental caries and plaque". And this editorial also reveals that Den-den was introduced to the Rocinha slum in Rio de Janeiro, Brazil, which at that time had 40 thousand inhabitants. It goes on to say: "results were significant because the poor families there were not in the habit of using a tooth brush. With the gum being chewed twice a day, dental plaque, especially among children, was reduced by $60 \%$ ". But no evidence was shown regarding how these findings were collected or evaluated. In fact, data never have been available (Vieira, 2015). "Humans are remarkably good at self-deception. But growing concern about reproducibility is driving many researchers to seek ways to fight their own worst instincts" (Nuzzo, 2015).

\section{The Impact of Values}

It has been suggested that xylitol inhibits the growth of Streptococcus pneumonia (Uhari, Kontiokari, Koskela, \& Niemela, 1996). This brings to mind the clinical trial that was made in Finland, where 306 children were randomized into two groups: a positive control who received sucrose gum and an intervention group who received xylitol gum ( $8.4 \mathrm{~g} /$ day). The primary endpoint was an episode of acute otitis media. Children were monitored for two months. Researchers concluded that xylitol gum can have a preventive effect on acute otitis media.

However, the editorial (Winter, 1996) of the same journal (British Medical Journal) in which this article was published discussed reasons why a UK ethics committee would not allow the trial made in Finland to be carried out. Sucrose gum is a risk for the dental health of children susceptible to caries and the studieswere not monitored by a pediatric dentist. Although the experiment did not 
go on for very long, there was time enough for the habit of chewing gum to develop. The harmful intervention should not have been made. Notwithstanding, researchers ignored the risk.

Trials with sucrose gum in Belize and in Finland were carried out when the procedures and international guidelines for human experimentation were already well accepted. Researchers were guided for what kind of feeling? Search for truth?

\section{Final Considerations}

It is well known that both chlorhexidine and fluoride play valuable preventive roles in dental disease, although chlorhexidine has an unpleasant taste, alters taste sensation and produces brown staining on the teeth, which is very difficult to remove (Eley, 1999), (Smith, Moran, Dangler, Leight, \& Addy, 1996). Fortunately, systematic reviews carried out all over the world concluded that more studies are necessary to confirm the possible effect of sugar free chewing gum on dental decay reduction (Touger-Decker \& van Loveren, 2003). In Brazil, competence and ethical concerns in medical research have greatly improved (Hossne, Bontempo, \& Vieira, 2010).

But it should be noted that researches on sugar-packed gum show that questions raised by human experimentation have no easy answers (Vieira, 2014). These examples emphasize the "need for greater awareness and restless analysis of the conflicting purposes of human experimentation: protecting man, advancing and improving well-being of society and future generations" (Katz, 1972). Science is a way of building knowledge about the universe, advancing and improving well-being of society and future generations, but methods and ethics are a must in research. In fact, science is inherently dependent on ethics but subject to corruption (Gardenier, 2011). And only "the process of critically examining past history will hopefully prompt a greater effort to curb potential abuse" (Bekier, 2010).

\section{References}

Bekier, M. (2010).The Ethical Considerations of Medical Experimentation on Human Subjects. http://www.qcc.cuny.edu

Editorial, O sorriso do chiclete (1994). Revista da Associação Brasileira de Odontologia.

Eley, B. M. (1999). Antibacterial Agents in the Control of Supragingival Plaque-A Review. British Dental Journal, 186, 286-296.

Gardenier, J. S. (2011). Chapter 2: Ethics in Quantitative Professional Practice. In Handbook of Ethics in Quantitative Methodology (pp. 15). New York: Routledge.

Hossne, W. S., Bontempo, C., \& Vieira, S. (2010). Chapter 26: Ethics of Research Involving Human Subjects: The Brazilian Experience. In Ibero-American Bioethics (pp. 333-341). New York: Springer International Publishing. https://doi.org/10.1007/978-1-4020-9350-0_26

Imfeld, T. (1999). Chewing Gum-Facts and Fiction: A Review of Gum-Chewing and Oral Health. Critical Reviews in Oral Biology \& Medicine, 10, 405-419.

https://doi.org/10.1177/10454411990100030901 
Jornal do Brasil (1984). Fabricante do chiclete Den-den diz que erro é do texto da publicidade.

Kakodkar, P., \& Mulay, S. (2010). Effect of Sugar Free Gum in Addition to Tooth Brushing on Dental Plaque and Interdental Debris. Dental Research Journal, 7, 64-69.

Katz, J. (1972). Experimentation with Human Beings (pp. 5). New York City: Russel Sage Foundation.

Lacaz-Netto, R., Macedo, N. L., \& Rossetini, S. M. O. (1986). Gomas de Mascar e Placa Bacteriana: Efeitos das Gomas de Mascar Ping-pong, Trident e Den-Den sobre a Formação da Placa Bacteriana-Estudo Piloto. Revista Gaúcha de Odontologia, 34, 107-110.

Mäkinen, K. K., Bennett, C. A., Hujoel, P. P., Isokangas, P.J., Isotupa K. P., Pape Jr., H. R., \& Mäkinen, P. L. (1995). Xylitol Chewing Gums and Caries Rates: A 40-Month Cohort Study. Journal of Dental Research, 74, 1904-1913. https://doi.org/10.1177/00220345950740121501

Mickenautsch, S., Leal, S. C., Yengopal, V., Bezerra, A. C., \& Cruvinel, V. (2007). Sugar-Free Chewing Gum and Dental Caries-A Systematic Review. Journal of Applied Oral Science, 15, 83-88. https://doi.org/10.1590/S1678-77572007000200002

Neder, A. C. (1981). Chiclete Anticárie (Nota prévia). Vida Odontológica, 8, 404.

Nuzzo, R. (2015). Fooling Ourselves. Nature, 526, 182-185. https://doi.org/10.1038/526182a

Paes-Leme, A. F., Koo, H., Bellato, C. M., Bedi, G., \& Cury, J. A. (2006). The Role of Sucrose in Cariogenic Dental Biofilm Formation-New Insight. Journal of Dental Research, 85, 878-887. https://doi.org/10.1177/154405910608501002

Pinheiro, C. E., Vono, A. Z., Pavarini, A., Bijella, M. F. T. B., Bastos, J. R. M., Moraes, N., \& Silva, O. P. (1985). Goma de Mascar Contendo Clorhexidina: Avaliação da sua Capacidade Antiplaca e Anticárie. Revista Gaúcha de Odontologia, 33, 67-70.

Smith, A. (2010). Effects of Chewing Gum on Cognitive Function, Mood and Physiology in Stressed and Unstressed Volunteers. Nutritional Neuroscience, 13, 7-16. https://doi.org/10.1179/147683010X12611460763526

Smith, A. J., Moran, J., Dangler, L. V., Leight, R. S., \& Addy, M. (1996). The Efficacy of an Anti-Gingivitis Chewing Gum. Journal of Clinical Periodontology, 23, 19-21. https://doi.org/10.1111/j.1600-051X.1996.tb00499.x

Touger-Decker, R., \& van Loveren, C. (2003). Sugars and Dental Caries. American Journal Clinical Nutrition, 78, 881S-892S.

Uhari, M., Kontiokari, T., Koskela, M., \& Niemela, M. (1996). Xylitol Chewing Gum in Prevention of Acute Otitis Media: Double Blind Randomised Trial. British Medical Journal, 313, 1180-1183. https://doi.org/10.1136/bmj.313.7066.1180

Vieira, S. (2014). Bioethical Questions in Brazilian Scientific Research. International Journal of Clinical Medicine, 5, 1006-1008. https://doi.org/10.4236/ijcm.2014.516130

Vieira, S. (2015). Not to Be Mentioned but Impossible to Keep Quiet about. Journal of Scientific Research and Reports, 8, 1-5. https://doi.org/10.9734/jsrr/2015/18426

Winter, G. B. (1996). Commentary: What about the Ethics? British Medical Journal, 313, 1183-1184. https://doi.org/10.1136/bmj.313.7066.1183 
Submit or recommend next manuscript to SCIRP and we will provide best service for you:

Accepting pre-submission inquiries through Email, Facebook, LinkedIn, Twitter, etc. A wide selection of journals (inclusive of 9 subjects, more than 200 journals)

Providing 24-hour high-quality service

User-friendly online submission system

Fair and swift peer-review system

Efficient typesetting and proofreading procedure

Display of the result of downloads and visits, as well as the number of cited articles Maximum dissemination of your research work

Submit your manuscript at: http://papersubmission.scirp.org/

Or contact ojpp@scirp.org 